JOURNAL OF SECURITY AND SUSTAINABILITY ISSUES

ISSN 2029-7017 print/ISSN 2029-7025 online

2019 June Volume 8 Number 4

https://doi.org/10.9770/jssi.2019.8.4(3)

\title{
Scopus
}

\section{FINANCIAL SUSTAINABILITY FACETS: THREATS TO THE TAX SYSTEM EMERGING FROM TAX INCENTIVES}

\author{
Greta Keliuotytė-Staniulèniené $\dot{1}^{1}$, Asta Mironenko² \\ Vilnius University, Sauletekio av.9, LT-10222 Vilnius, Lithuania \\ E-mails: ' greta.keliuotyte-staniuleniene@evaf.vu.lt; ${ }^{2}$ asta.zeimyte@yahoo.com \\ Received 10 November 2018; accepted 25 March 2019; published 30 June 2019
}

\begin{abstract}
Scientific literature particularly emphasizes the threats to the tax system emerging from tax incentives, as well as the need to control them in order to get the desired effect in society and to ensure the sustainability of public finance. Nevertheless, it can be noticed that relatively weak tax incentives control mechanisms exist in practice, in comparison with control programs of government spending. Only a small number of countries use tax incentives assessment models to justify political decisions. Evaluating Lithuanian practice and comparing it with other countries, it is obvious that Lithuanian government has no legal mechanism for evaluating the necessity and efficiency of tax incentives. Due to this reason, the tax incentives assessment model is necessary in order to evaluate Lithuanian personal income taxation and create competitive and sustainable tax system. The aim of the paper is to form the assessment model for income tax of individuals incentives, based on theory and practice of foreign countries and international organizations, and apply it to evaluate the impact of personal income tax incentives on public finance in Lithuania. As a primary task, the authors conducted an analysis of a number of theoretical and practical tax incentives assessment models. Second, personal income tax incentives are analyzed from different perspectives - as tax benefit, as tax expenditure, and as fiscal measure. Finally, the authors suggest the complex and multifaceted model that can be used to evaluate the impact of income tax of individuals incentives on public finance and their sustainability. It is believed that the results obtained due to the study carried out for the purpose of the present paper will help to shape favorable personal income taxation system for sustainable development process. The study was conducted using the methods of academic literature and statistical data analysis, meta-analysis, qualitative content analysis and correlation-regression analysis.
\end{abstract}

Keywords: tax incentives; income tax of individuals; fiscal sustainability; impact on public finance

Reference to this paper should be made as follows: Keliuotytė-Staniulėnienė, G.; Mironenko, A. 2019. Financial sustainability facets: threats to the tax system emerging from tax incentives, Journal of Security and Sustainability Issues, 8(4): 581-595.

https://doi.org/10.9770/jssi.2019.8.4(3)

JEL Classifications: H34, H50, K36

\section{Introduction}

Strong public finances guarantee not only an appropriate distribution of resources and reallocation of income, and a macroeconomic stability, but also affects the economic growth and development of a State (Afonso et al, 2005; Barrios, Schaechter, 2008; Öberg, 2010; Luzgina, 2017; Osipov et al., 2018; Vandina et al., 2018; Tvaronavičienè, 2018; Katina et al., 2018).

In this context, special role is played by the income tax of individuals (ITI) that is to a larger or smaller extent applied to all residents of the country: the rate of the ITI, tax benefits, the efficiency of the tax - have been a high-profile subject of public discussions. Still, one of the most controversial themes in the context of the personal income tax is tax benefits (incentives) - not mandatory in theory, however in practice, a component of the tax used in nearly all States. Nevertheless, their fiscal impacts are not always clear and their effectiveness and efficiency as a policy instrument needs to be carefully evaluated, especially in the present context of constrained 
public finances (Barrios et al., 2018). It is stated that tax incentives schemes my appear to be opaque, costly and often ineffective in reaching stated goals (Redonda et al., 2018; Tarasova et al., 2018). However, only a small part of the States employs evaluation models underlying political decisions regarding the ITI: for the purpose of the OECD analysis only seven countries submitted the required data out of the total 34 Member States (Collin, Walsh, 2011). In general, that cannot be considered to be an example of good practice. OECD has noticed that although incentive expenses and the impact analysis may be a rather complicated exercise, a 'much larger problem may be an inability to attempt to perform such analysis' (OECD, 2010a). There is a common agreement on the need to design an evaluation model to comprehensively assess the impact of the income tax of individuals upon public finances.

Although the very subject of the ITI has been highly in the focus in the political and public domain, in Lithuania the subject has not been given sufficient attention. An assessment of the practice of the Lithuanian State in a wider context and in comparison with the other States concludes that differently from other States (Thöne, 2011; U.S. GAO, 2012; Jacobsen et al, 2010) Lithuania has not designed any incentives assessment model. In view of the existing issues related to the treatment of tax incentives the purpose of the present study is to design a model for the assessment of the impact of tax incentives upon the public finances, and apply it for the analysis of the Lithuanian ITI incentives.

The first part of the present paper covers an analysis of theoretical and practical possibilities of tax incentives. In the second part of the paper presents a model for the assessment of the ITI incentives upon the public finances. The third, final part of the paper offers an analysis of the tax incentives set forth in Article 21 of the Law on Income Tax of Individuals of the Republic of Lithuania and defines and identifies the impact of such tax incentives upon public finances.

\section{Analysis of Theoretical and Practical Possibilities to Assess the ITI Incentives}

In practice, the necessity to assess the ITI incentives is not that obvious as in the case of expenses, because in the budget structure such incentives are carried in the revenue side and are treated as revenues foregone rather than as expenses, and are on a regular basis estimated, analysed and substantiated. Furthermore, such tax incentives are given effect in laws, and become their integrated part, as opposed to the public expenditure programmes, and therefore are to a lesser extent questioned. Nevertheless, it has been often maintained (OECD, 2010a; Dean, 2012; Roin 2003) that such tax incentives should be treated as equivalent to Government subsidies or transfers, because eventually they lead to budget expenditure, which, however, in this case are indirect.

Research literature on the subject offers three general approaches towards the costs created by tax incentives: revenue foregone, revenue gain and outlay equivalence methods. The incentive evaluation analysis from the revenue foregone viewpoint (Redonda, 2016) covers only an estimation of the difference between the revenue collected under a benchmark standard and the the current tax system. The method, however, has been heavily criticised in research literature (Rabin, 1992; OECD, 2010a) for several reasons: first, the method relies on an assumption of unchanging behaviour, which means that any changes in the behaviour of taxpayers resulting from the introduction of a tax incentive are disregarded; second, the method fails to take into account the interaction between the incentives which may eventually cause inaccuracies in estimating the revenue foregone. On the positive side, the revenue foregone method does not require accumulating of complex statistical data (as the revenue statistics is sufficient) or relaying on subjective assumptions, therefore due to its simplicity the method is a preferred approach in most countries assessing the impacts of tax incentives (e.g. in Germany, France and the Great Britain) (Polackova Brixi et al, 2004).

The revenue gain approach (Tipps, Webb, 1980) is based on an ex-ante approach and measures the anticipated revenue gain that would arise from abolition of a specific tax expenditure. This approach addresses the main shortcomings of the revenue foregone method by including in the analysis the taxpayer responses, as well as the interaction between the different incentives. However, the inclusion of the latter elements at the same time means the appearance of certain level of subjectiveness, because it relies on assumptions on the changes 
in behaviour and elasticity (Polackova Brixi et al, 2004). However, the estimations under the revenue gain method require econometric, microsimulation models, evaluations of control groups that in practice requires large volumes of statistical data and intricate studies (Rashkin, 2007; Pitter, 2013). That limits possibilities for applying the method.

Finally, the outlay equivalence approach (Davidon, 2012) involves an estimation of the amount to be allocated as direct financing through Government programmes, in order to achieve the effect in the economy as applying tax incentives; the exercise assesses whether the desired effect is more efficiently attained by way of direct subsidy, or by applying tax incentive. Just like in the case of revenue foregone the calculation relies on an assumption that the behaviour does not change (Hashimzade et al, 2014). However, due to its limited applicability the outlay equivalence method is applied rather infrequently. According to OECD, lately only Sweden (Sveriges Regeringen, 2016) uses the methods as an additional method supplementing the revenue foregone computations (OECD, 2010a).

A comparison of possibilities to practically apply each of the methods and their results demonstrated that the costs of applying of tax incentives under the revenue gain approach are less than computed under the revenue foregone approach. The result can be explained by a changes behaviour of taxpayers (Commonwealth of Australia, 2015). But the computations applying the outlay equivalence approach yield an opposite result - the costs of applying the tax incentives are marginally higher than computed by way of revenue foregone approach, because in the case of direct financing taxation is involved which actually determines that at the same costs the incentives yield much stronger effect than implementing a respective direct financing programme (Brown, 2004). It should be noted that none of the approaches used to quantify the costs created by tax incentives is adequate for a comprehensive evaluation of the incentives of the ITI upon public finances. In view of the above it is necessary to analyse the impact evaluation methods and models currently used in practice.

Both foreign authors (Tyson, 2014; Dean, 2012; Collins, Walsh, 2011) and the relevant international organisations (OECD, 2010a) noted that in general there were very few States quantifying tax incentives, and most of them limit themselves to estimation of revenue forgone. Still, the analysis of the guidelines assessing the effects of tax incentives provided by public authorities allows a conclusion that quite a number of States in the world (for instance, Australia (Commonwealth of Australia, 2017), Canada (Department of Finance Canada, 2017), USA (U.S. Department Of The Treasury, 2017), Ireland (Department of Finance, Ireland, 2016) make efforts not only to quantify the costs incurred due to the tax incentives, but also treat tax incentives as a political measure of economic and social regulation. The practical cost quantification exercise supplements the theoretical models designed in the area.

According to OECD, an ideal evaluation should be based on a counterfactual analysis and consist of an ex ante and ex post evaluation (OECD, 2010b). An ex ante evaluation is designed to provide a rationale of the incentive (why is the government intervention necessary), determine the objectives of applying an incentive (the objectives in this case should be SMART, i.e. specific, measurable, achievable, relevant, and time bound), in addition to the evaluation of alternative decisions which means that an incentive must be demonstrated as an optimal solution with respect to the effects of redistribution, behaviour and revenues. Having selected the most appropriate incentive implementation form, and after the incentive is given effect, an ex post evaluation, to an extent possible, comparing the performance of the incentive with a counterfactual situation from the viewpoint of efficiency, justice, redistribution, compliance and administrative costs (OECD, 2010b).

Germany employs a standard incentive evaluation model consisting of five elements (Thöne, 2012): first, an incentive is discussed as a legal constructus, i.e. its statutory objective, history, etc.; the second step involves the determination of the incentive's fiscal value using the revenue forgone method; third, references are made to previous evaluations, and an overview of the academic papers relevant in relation to the incentive; the fourth step is a step of the principal evaluation which includes an evaluation in the context of the overall policy (transparency, rationale), an evaluation of the element of the incentive and the very incentive as a constructus (whether or not the specific intervention on the part of the State is the most appropriate, is the type of the 
incentive most appropriate, whether its construction was the best in order to attain the prescribed objective), in addition to the evaluation of the incentive's effect (whether the incentive is efficient and cost-effective); the fifth step represents a summary of the above aspects, and includes proposals regarding the further actions. The key methods used for the purpose of assessing the incentives on the basis of the model discussed are econometric models and a meta-analysis (Thöne, 2012). Thus, the model used in Germany is rather extensive, as it addressees not only the most important aspects of efficiency, effectiveness and reasonableness of an incentive as a political measure; it also contains a number of elements of descriptive nature. It should be noted that a comparison of the model with the other possible approaches shows that the model does not include an ex ante evaluation which is important even before the approval of the incentive.

Contrary to the German model, the incentive evaluation model used in Ireland is based on distinguishing the ex ante and the ex-post evaluation (as proposed by the OECD). The ex-ante evaluation of incentives is necessarily performed before the introduction of the incentive element to the tax structure. An ex-ante model includes five key aspects (Department of Finance, Ireland, 2014): the objective (clearly defined); substantiation of the intervention (related to market failure); best alternative (the incentive is more efficient than direct expenditure); economic effect (analysis of the causal links between the economic objectives and the application of the incentives); the costs (cost-benefit analysis, construction of the scenario). An ex-post evaluation in the priority manner focuses on the relevance of the incentive. This is followed by a quantification of the costs of applying this tax element (most often applying the revenue foregone method). And finally, the analysis focuses on the efficiency of the incentive as a policy tool, i.e. whether the costs resulting from the application of the tax incentive are adequate with respect to the attaining the objectives. This analysis provides an answer whether the tax incentive is the most appropriate means of public intervention, however, it fully discloses the impact of the tax incentive upon public finances.

The application of the models makes it possible to consider whether the application of the tax incentives is $n$ efficient means, or whether its should be replaced by a different regulation. With a view to analysing the impact of the ITI incentives upon public finances, the models as discussed above cannot be fully applied. On the one hand, they are excessive, because they include an analysis of the historic perspective of the tax incentive as a legal construct. On the other hand, the models can be treated as insufficient, because, irrespective of the fact that they include elements (such as analysis of economic effect, efficiency and relevance), that partly allows assumptions on the impact upon public finances, none of the approaches as referred to earlier provides an answer whether the impact of the ITI incentive upon public finances is positive, or, on the contrary, negative. In view of the above it is necessary to have such model designed.

\section{A Model for the Evaluation of Impact of ITI Incentives Upon Public Finance}

In order to identify the most appropriate method for the evaluation of the impact of ITI incentives upon public finance, a primary task is to define the concept of 'impact'. A number of authors analysing the impact (OECD, 2006; Stern et. al. 2012; Gertler et al, 2016) have emphasised that the impact must be related to the direct and indirect result with respect to the entire area being studied. It follows that an evaluation of the impact of tax incentive upon public finances may not be limited to the share of the budget revenue loss; the exercise should include an assessment of the outcome of an introduced incentive element upon the entire area of public finance. In theory, researchers distinguish three functions of public finance that include collection of revenues, the use of revenues, and the control of the generation and the use of revenues (Meidūnas, Puzinauskas, 2003). The model proposed by the authors of the present paper is based on the three functions as referred to above, each of which is assessed according to the criteria as defined below; the overall conclusions of the study covered by the present paper leads to conclusions on a positive or negative impact of tax incentives upon public finance.

1. Revenue collection. The analysis of theoretical and practical possibilities to evaluate the impact of ITI incentives has shown that most of the States calculate the budget revenue loss under the revenue foregone method. Furthermore, no evidence has been obtained that an estimation of the budget revenue loss according to the revenue foregone is to a large extent different from the results obtained when computed by other methods 
(e.g. Carsso, Steurle (2003)). Thus, in the proposed model the impact upon the budget revenue collection is evaluated by quantifying the budget loss according to the revenue foregone method. The statistical analysis of the indicators covers a period of at least five years. A broader approach towards the estimation of the ITI incentive indicators and their averages in order to identify the level of materiality of the budget loss due to the introduction of a specific incentive. An estimate of the ITI incentives indicator exceeding the average shall be considered to be material, and relatively immaterial in case it is below the average.

2. Use of revenues. The second part of the model presents an analysis of the legal acts establishing and regulating the ITI incentives in the taxation structure, and whether the construct of the tax incentive contains a reasonable objective. The evaluation is then carried out using the SMART criteria (Department of Finance, Ireland, 2014). That means that every objective is evaluated in terms of five criteria (Doran, 1981): whether or not the objective is specific, measurable, achievable, relevant, time bound. An evaluation according to the SMART criteria makes it possible to assess whether the objective pursued by introducing an incentive in the tax structure is appropriate and reasonable. Taking into account the fact that policy of tax incentives (or tax expenditure) has been called "hidden" or "submerged" form of government policy (because its design makes government's role as the provider of benefits less visible) (Shanks-Booth, Mettler, 2019), proper definition of their objective is crucial. Such a conclusion may be drawn up only if the objective pursued meets at least three out of five above criteria. On the other hand, despite a reasonably defined objective fully compliant with the criteria in question, another important requirement is to select a proper means to attain the objective. In this specific case the task is to prove the existence of interdependence between the indicator defined in the objective of the incentive, and the rate of the incentive allowed to the resident. The existence of such interdependence is identified and defined using the correlation and regression analysis methods. The regression analysis method does not only determine the existence of the interdependence between the dependent variable, i.e. the objective pursued by granting tax incentives, and the independent variable (application of the incentive to the income tax of individuals), as well as the strength of such relation. The analysis of the second part of the evaluation model has led to a conclusion regarding whether or not waiving part of the tax income is meaningful, and whether that would lead to any economic or social changes in the State. 


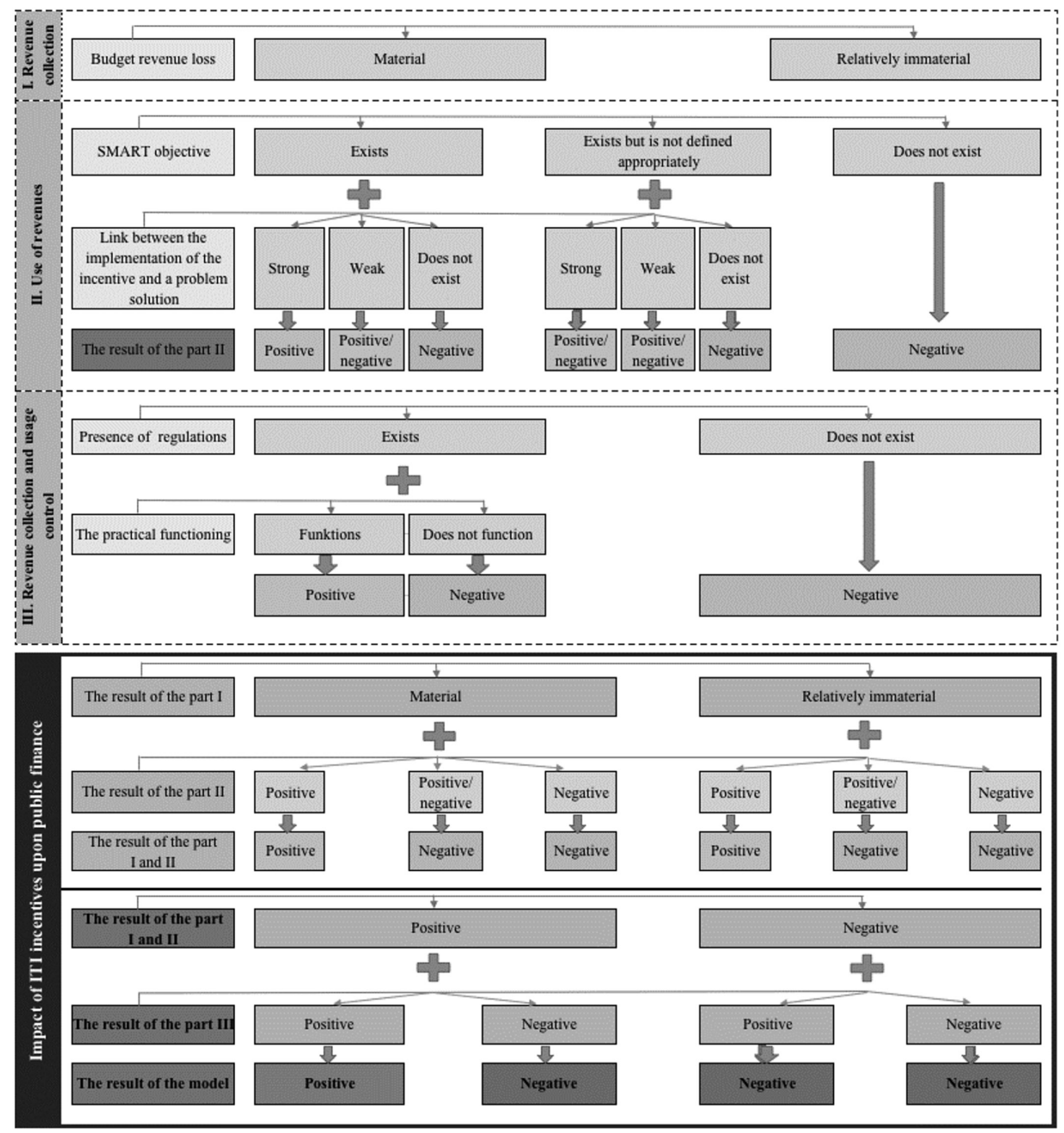

Fig. 1. A model for the evaluation of impact of ITI incentives upon public finance

Source: composed by the authors.

3. Revenue collection and usage control. Since tax incentives are not considered to be a category of budgetary expenditures, they are also exempted from the control ordinarily applied to expenditures. With a view to assessing whether or not the application of the incentives produces a positive or a negative effect upon the enforcement of control, and the transparency of public finance, the model must include an assessment of the legal regulation effective in the State in relation to incentives and identify whether the State has put in place any regulations on the control of tax incentives. The elements above were evaluated using a qualitative study method. An analysis of the content of legal acts governing the ITI incentives was carried out in order to determine the presence of any regulations on the control of the ITI incentives. Furthermore, in order to assess the practical functioning of the control mechanism the content analysis method was employed to analyse the 
functions carried out by the relevant responsible authorities or the relevant regulations. Having considered the relevant regulations, the aspects of their practical enforcement and operation the authors of the present study concluded on the impact of the ITI incentives upon the transparency of the taxation system and public finances. A summary evaluation model is graphically shown in the Figure 1 that distinguishes the key functions of public finances. The ITI incentives impact assessment model allows conclusions regarding the overall impact of the ITI incentive upon public finance, integrating the entire process ranging from the collection of revenues and their expedient use to the control over the revenue collection and the use creating preconditions for the legitimacy of the taxation system. The model goes beyond creating the preconditions for the conclusions on the overall impact on publish finance, as it identifies the areas to be improved.

\section{Evaluation of Impact of ITI Incentives in Lithuania Upon Public Finance}

The Law on Income Tax of Individuals of the Republic of Lithuania (hereinafter - LITI) is an object of regular changes planned by each new Governments of the country. Despite the numerous and ongoing improvements in the area of tax incentives, the Lithuanian LITI still provides for quite a number of different incentives in the form of zero taxation rate. In summary, the incentives may be divided in three groups (Table 1).

Table 1. Tax incentives provided for in the Law on Income Tax of Individuals of the Republic of Lithuania

\begin{tabular}{|l|l|}
\multicolumn{1}{c|}{ Subject to the terms and conditions defined in the Law: } \\
\hline $\begin{array}{l}\text { allowances and compensations, insurance benefits, pension benefits and pension annuities, interest, income from agricultural } \\
\text { activities; charity, gifts, inherited income, income from the sale or other transfer of assets not assigned to individual activities, } \\
\text { income from the sale of financial instruments, amounts awarded by courts, scholarships and benefits, premiums, bonuses, lottery } \\
\text { wins, donations and gifts received in the course of a political campaign, funds for the maintenance of the clergy, attendants at } \\
\text { religious ceremonies and support staff, income received by mariners'on a sea trip, income received from the European Communi- } \\
\text { ties related to employment relations, late interest, income received as a compensation for provided services according to a service } \\
\text { receipt. }\end{array}$ \\
\begin{tabular}{l} 
Amount of tax-free income \\
Additional amount of tax-free income \\
\hline Subject to the terms and conditions defined in the Law:
\end{tabular} \\
\hline contributions to pension funds, life insurance premiums; amounts paid for vocational training and/or studies \\
\hline Subject to the terms and conditions defined in the Law: \\
\hline Activity on the basis of business certificate; individual activity
\end{tabular}

Source: composed by the authors on the basis of the Law on Income Tax of Individuals of the Republic of Lithuania, 2002

The ITI incentives existing in Lithuania are particularly numerous, statistical data are readily available, therefore the model for assessing the impact of the ITI incentives upon public finance is applied to one of the incentive groups indicated above, i.e. the expenses incurred by an individual deducted from the income treated for tax purposes. This group of incentives was selected for the purpose of the study also having considered that losses in the budget incurred due to the compensation of the deducted expenses are one of the largest, which requires this type of incentives to be specifically prioritised as a study object. A model for the evaluation of impact of ITI incentives upon public finance is applied to three incentives effective at the time of the study while analysing the incentives in parallel - the incentives in respect of the contributions to pension funds, life insurance premiums, fees for vocational training and/or studies. The data used for the purpose of the study refer to the period from 2005 to 2016.

1. Revenue collection. The estimations of the loss in the Lithuanian state budget due to the applied incentives are presented in Table 2. 
Table 2. Statistical characteristics of the ITI loss (EUR, 2004-2016)

\begin{tabular}{|l|c|c|c|}
\hline \multicolumn{1}{|c|}{ Statistical characteristics of the ITI loss } & $\mathbf{2 0 1 4}$ & $\mathbf{2 0 1 5}$ & $\mathbf{2 0 1 6}$ \\
\hline Average & $29,750,079$ & $23,993,514$ & $26,362,499$ \\
\hline Average adjusted for the loss due to tax-exempt amount of income & $14,187,576$ & $15,069,603$ & $16,030,881$ \\
\hline Median & $14,481,001$ & $5,410,780$ & $5,112,712$ \\
\hline The average adjusted for the loss due to tax-exempt amount of income & $13,964,487$ & $2,800,000$ & $4,100,000$ \\
\hline
\end{tabular}

Source: composed by the authors on the basis of the data provided by the Ministry of Finance and the STI

The loss in the revenue resulting from the application of the ITI incentive for life insurance contributions should be considered material, because the percentage of the ITI revenue loss in the period concerned increased from 4.43 per cent to 17.74 per cent, which accounts for more than 1 per cent of the tax revenues of the State. In the period from 2005-2016 the rate of tax revenue loss due to the incentive to the total revenue of the budget was decreasing, and its fluctuation ranged from 6.03 per cent to 18.5 per cent. The considerable significance of the incentive is further evidenced by the fact that the amount of revenue loss is nearly twice as large as the average ITI incentives (having adjusted for a significant incentive related to the tax-exempt income, the average is exceeded by four times) (see Table 2).

The revenue loss due to the ITI incentives related to studies and/or vocational training fee should be considered insignificant. The period being analysed also recorded an increase in the rate of benefiting from the incentive, and lately the budget revenue foregone for this specific reason accounts for about 3 per cent of the total income tax of individuals. The share of the budget revenue loss due to this particular incentive accounted for 1.03 per cent (2016) and 9.85 per cent (2010) of the total revenue foregone. The tax revenue loss due to ITI incentives applied to the fees for studies and/or vocational training is below the relevant average even having eliminated the impact of the tax-exempt income. The loss caused by this incentive is lower than the median of the sample being analysed (both in overall terms and having eliminated the impact of the tax-exempt income, Table 2).

The budget revenue loss caused by the ITI incentive for contributions to pension accumulation funds should be considered insignificant; in 2016 the loss concerned accounted for as little as 1.36 per cent, and on average for 0.5 per cent of the total ITI revenue. In relation to the total tax revenues of the State the ratio ranged from 0.02 per cent to 0.1 per cent, while the share of the total income foregone accounted for 0.5 per cent. Besides, a comparison of the revenue loss due to the incentive on pension contributions to pension accumulation funds with other incentives of the ITI even having adjusted the impact of the tax-exempt income, showed that the loss was below $1 / 3$ of the average (see Table 2).

2a. Use of the tax expenditure: formulation of targets. The explanatory note to the draft LITI defines the following objectives related to the establishment of the incentives analysed for the purpose of the present paper (Ministry of Finance of the Republic of Lithuania, 2002): 'The provisions of the law being submitted shall create the following preconditions: $<\ldots>$ to establish pension funds $<\ldots>$. $<\ldots>$ deduct limited amount expenses for education thus creating more advantageous conditions for pursuing higher education'. The explanatory note remains silent on the incentives for life insurance premiums, however the overall goal is reflected in the supporting documents of the draft law, and is defined as encouragement of residents to accumulate funds in pension funds and acquire life insurance coverage (Committee on Budget and Finance of the Seimas of the Republic of Lithuania, 2002). The results of the analysis of the objective carried out with reference to SMART criteria are summarised in Table 3. 
Table 3. The consistency of the ITI incentives with the requirements of reasonable objective

\begin{tabular}{|l|c|c|c|}
\hline $\begin{array}{l}\text { Incentive } \\
\text { Objective }\end{array}$ & $\begin{array}{c}\text { ITI incentive for life } \\
\text { insurance premiums }\end{array}$ & $\begin{array}{c}\text { ITI incentive for studies } \\
\text { and vocational training }\end{array}$ & $\begin{array}{c}\text { ITI incentive for pension contributions } \\
\text { to pension accumulation funds }\end{array}$ \\
\hline specific & not compliant & not compliant & not compliant \\
\hline measurable & not compliant & not compliant & not compliant \\
\hline achievable & compliant & compliant & compliant \\
\hline realistic & compliant & not compliant & compliant \\
\hline timebound & not compliant & not compliant & Objective defined \\
inadequately
\end{tabular}

Source: composed by the authors

For the purpose of assessing the specificity of the objectives pursued by the incentives being examined, it should be noted that the objectives are defined in rather abstract terms; despite targeting certain issues relevant for the society (low living standards of pensioners, ageing of the society, inadequate functioning of the social insurance system), the regulations supporting the LITI the incentives are not clearly linked to the problems. In the absence a clear link between the incentives and the issues in the society, the laws and other legal acts do not provide any clear-cut criteria facilitating an assessment whether or not the incentives attaining their objective (on the basis of legal acts measurement c+riteria may be only presumed). On the other hand it may be concluded that all the three incentives should be assessed positively from the view point of the possibility to achieve the objective - an incentive to save for pension in the form of life insurance, or ensure some security in case of an accident, an encouragement to seek higher education, creation of advantageous conditions for that, and addressing the problems in the pension system - are the tasks assigned to the competence of the State, and as such should be assessed as realistic. The enforcement of all the incentives is not defined in terms of the times of their application.

From the viewpoint of their meaning the objectives should be assessed in terms of the take-up of the incentive. The obtained evaluation results are presented in Table 4 . The data presented in the Table clearly demonstrate that the take-up rate of the incentive for life insurance contributions exceeded 70 per cent throughout the entire period being considered, therefore it may be concluded that the incentive is very important for residents and is being extensively used. During the recent years the rates of use of the ITI incentive with respect to studies and vocational training decreased and was recorded at 52.26 per cent (2016) (2016). Only about half of those entitled to this incentive actually use it, therefore it may be concluded that the incentive is not particularly important for the society. Although the rate of take-up of the incentive related to pension contributions was decreasing (e.g. from 91.46 per cent in 2007 to 77.79 per cent in 2016), the usage frequency is still exceeding the threshold of 70 per cent (see Table 4). This allows a conclusion that this type of tax incentive is highly relevant for the population.

Table 4. Take up of incentives of the income tax of individuals in 2004-2016

\begin{tabular}{|c|c|c|c|}
\hline Year & $\begin{array}{c}\text { Re: ITI refunds } \\
\text { for pension contributions }\end{array}$ & $\begin{array}{c}\text { Re: ITI refunds for life } \\
\text { insurance premiums }\end{array}$ & $\begin{array}{c}\text { Re: ITI refunds } \\
\text { for studies and vocational training }\end{array}$ \\
\hline $\mathbf{2 0 0 5}$ & 76.88 & 74.43 & 74.91 \\
\hline $\mathbf{2 0 0 6}$ & 83.73 & 75.66 & 78.45 \\
\hline $\mathbf{2 0 0 7}$ & 91.46 & 76.28 & 82.34 \\
\hline $\mathbf{2 0 0 8}$ & 78.44 & 76.77 & 84.86 \\
\hline $\mathbf{2 0 0 9}$ & 85.88 & 75.23 & 75.68 \\
\hline $\mathbf{2 0 1 0}$ & 82.53 & 75.28 & 72.70 \\
\hline $\mathbf{2 0 1 1}$ & 82.15 & 77.15 & 73.42 \\
\hline $\mathbf{2 0 1 2}$ & 83.41 & 78.60 & 73.18 \\
\hline $\mathbf{2 0 1 3}$ & 81.44 & 77.27 & 69.34 \\
\hline
\end{tabular}




\begin{tabular}{|l|l|l|l|}
\hline $\mathbf{2 0 1 4}$ & 78.96 & 75.35 & 60.52 \\
\hline $\mathbf{2 0 1 5}$ & 77.91 & 74.53 & 58.42 \\
\hline $\mathbf{2 0 1 6}$ & 77.79 & 73.82 & 56.26 \\
\hline
\end{tabular}

Source: composed by the authors on the basis of the data submitted by the STI

The analysis of the objective based on the SMART criteria showed that the procedure for the implementation of the ITI incentive insufficient attention was dedicated to the definition of the objectives pursued by introducing the incentives in the ITI structure. The objectives of the incentives fail to comply with the requirements set forth for a reasonable objective, thus it may be concluded that in respect of all the three ITI incentives the objective is not properly defined (Table 3 ).

2b. Use of the tax expenditure: efficiency of the measure. The evaluation of the efficiency of an incentive is conducted on the basis of the variables presented in Table 5. For the purpose of the study the incentives applied with respect to life insurance premiums are related to the change in the poverty level, the incentives for studies are linked to the number of students trained at universities, and the incentive applied to the voluntary pension accumulation is linked to the number of persons saving in pension funds and employed residents.

Table 5. Variables used for the regression

\begin{tabular}{|l|l|l|}
\hline \multicolumn{1}{|c|}{ Independent variables } & \multicolumn{1}{c|}{ Dependent variables } \\
\hline & Life insurance incentives as part of revenue foregone & Risk of poverty threshold \\
\hline & $\begin{array}{l}\text { Studies incentives as part of the loss in the ITI } \\
\begin{array}{l}\text { Incentives with respect to voluntary pension accumulation } \\
\text { as revenue foregone }\end{array}\end{array}$ & $\begin{array}{l}\text { Number of specialists trained at universities } \\
\text { employed persons }\end{array}$ \\
\hline
\end{tabular}

Source: composed by the authors

The results of correlation-regression analysis (Table 6) showed the existence of a strong statistically significant direct relation between the part of the loss in the State budget due to the incentive on life insurance and the risk of poverty threshold. The results of the study carried out led to a conclusion on the existence of a strong, direct and statistically significant link between the loss in the ITI revenue due to the incentives for studies and the dependent variable - the number of specialists trained at universities.

Table 6. Efficiency of the ITI incentives application - results of a regression analysis

\begin{tabular}{|c|c|c|c|c|c|c|c|c|}
\hline \multicolumn{3}{|c|}{$\begin{array}{l}\text { Incentive for life insurance } \\
\text { contributions and } \\
\text { the risk of poverty threshold }\end{array}$} & \multicolumn{3}{|c|}{$\begin{array}{l}\text { Incentive for studies and } \\
\text { the number of trained specialists }\end{array}$} & \multicolumn{3}{|c|}{$\begin{array}{l}\text { Incentive for pension accumulation } \\
\text { contributions and the relative number } \\
\text { of participants in pension funds }\end{array}$} \\
\hline $\mathbf{R}$ & \multicolumn{2}{|c|}{0.86} & $\mathbf{R}$ & \multicolumn{2}{|c|}{0.91} & $\mathbf{R}$ & \multicolumn{2}{|c|}{0.73} \\
\hline $\mathbf{R}^{2}$ & \multicolumn{2}{|c|}{0.75} & $\mathbf{R}^{2}$ & \multicolumn{2}{|c|}{0.84} & $\mathbf{R}^{2}$ & \multicolumn{2}{|c|}{0.53} \\
\hline $\mathbf{F}$ & \multicolumn{2}{|c|}{0.000244} & $\mathbf{F}$ & \multicolumn{2}{|c|}{0.0000264} & $\mathbf{F}$ & \multicolumn{2}{|c|}{0.006697} \\
\hline Variables & Coefficients & T-stat. & Variables & Coefficients & T-stat. & Variables & Coefficients & T-stat. \\
\hline Const & 74.27 & 1.1186 & Const & 11806.33 & 5.1305 & Const & 0,003 & 1.7326 \\
\hline $\mathbf{X}_{1}$ & 0.000008 & 5.5493 & $\mathrm{X}_{1}$ & 0.000964 & 7.2866 & $X_{1}$ & 2.481 & 3.4065 \\
\hline
\end{tabular}

Source: composed by the authors

The results of the analysis have shown that the relation between the budget loss because of the ITI incentives for pension contributions and the relative number of persons saving in pension funds and the total number of employees is statistically significant, positive and strong (Table 6). 
The summarised results of the analysis of the impact of the first and second ITI incentives upon public finance obtained on the basis of the estimations (Table 6) and the logical scheme of the proposed evaluation model shown in Figure 1 are shown in Table 7.

Table 7 The impact of the ITI incentives upon the implementation of the public finance formation and usage functions

\begin{tabular}{|l|l|c|l|l|c|}
\hline & $\begin{array}{c}\text { Link between } \\
\text { Reasonable } \\
\text { objective } \\
\text { implementation } \\
\text { of the incentive and } \\
\text { problem solution }\end{array}$ & Conclusions & Budget loss & $\begin{array}{c}\text { Summarized } \\
\text { conclusion of } \\
\text { the first two parts } \\
\text { Impact }\end{array}$ \\
\hline $\begin{array}{l}\text { ITI incentive for life insurance } \\
\text { premiums }\end{array}$ & $\begin{array}{c}\text { inadequately } \\
\text { defined }\end{array}$ & strong & positive / negative & significant & negative \\
\hline $\begin{array}{l}\text { ITI incentive for studies and } \\
\text { vocational training }\end{array}$ & $\begin{array}{c}\text { inadequately } \\
\text { defined }\end{array}$ & strong & positive / negative & insignificant & positive \\
\hline $\begin{array}{l}\text { ITI incentive for pension } \\
\text { contributions to pension } \\
\text { accumulation funds }\end{array}$ & $\begin{array}{c}\text { inadequately } \\
\text { defined }\end{array}$ & strong & positive / negative & insignificant & positive \\
\hline
\end{tabular}

Source: composed by the authors

In the case of the ITI incentive with respect of the life insurance premiums, where the objective of the incentive has not been defined properly, there is a strong relation between the application of the incentive and solution of the problem, and the budget revenue loss is significant, the impact upon public finance should be assessed negatively. The incentives with respect to studies and whose objective was defined inadequately, the link between the variables demonstrating the efficiency of the incentive is strong, and the budget loss should be assessed as insignificant, a generalisation of the first two functions of public finance the impact upon public finance should be assessed as positive. In the case of the ITI incentive for pension contributions, where the objective was not adequately defined, the link between the application of the incentive and the problem solution is strong and the budget loss is insignificant, the impact upon the formation and the use function of public finance is positive.

3a. Collection and use control: existence of legal regulation. Neither the LITI, nor any supporting clearly defines the control of the ITI incentives. The only control means is the annual income tax returns - a mandatory precondition for taking advantage of the incentives referred to in Article 21 of the LITI (Ministry of Finance, 2002). Still, tax returns are not sufficient to control the volumes of revenues foregone, and especially to ensure the control of the use of tax expenditure. Any State should have a regulation framework for reviewing the functioning of the incentives; such regulation would facilitate a conclusion whether the ITI incentive is producing the designed impact for resolving certain problem existing in the society.

3b. Collection and use control: practical implementation. It should be noted that Lithuania has not designed or put in place any legal regulation for collecting and use of incentives, therefore the practical implementation of such regulation is not possible either. In Lithuania, reviewing of the ITI incentives is to a larger extent triggered by political initiatives (e.g. Ministry of Finance of the RL (2008)) and is particularly related to the advent of new governing parties. Therefore, it would not be absolutely correct to say that the control over the collection of revenue or use of tax expenditure does not exist. However, such evaluations are very rare, most often related to deliberation of some draft laws, for instance the conclusions of the Committee of Budget and Finance (2016) of the Seimas of the Republic of Lithuania refer a quantification of the ITI incentive with respect to life insurance premiums, however, limited to simply referring to fiscal impact.

A conclusion may be drawn up that Lithuania has not put in place a legal regulation establishing control over the use of tax loss and tax expenditure, and in practice such control attempts are very rare and is related to political initiatives. For that reason, and on the basis of the results of the study covered by the present paper and the evaluation model logics as defined in Fig. 1, a conclusion may be drawn up that the impact of the incentives upon public finance is negative. 


\section{Conclusions}

The analysis of the theoretical methods for the evaluation of incentives showed that in terms of demonstrating the impact upon public finance the optimal methodology is the one based on revenue gain estimation; still, because of the inadequacies of its practical adaptability the method does not produce a comprehensive evaluation of the impact of the ITI incentives upon public finance.

Having comprehensively analysed the qualities of practical or theoretical models for assessing incentives, the authors of the present study proposed an evaluation of the impact upon public finance through an analysis of the effect of ITI incentives upon the implementation of functions of public finance. First, the impact upon collection of revenue is assessed by analysing the materiality of the revenue loss due to the application of the incentive, Second, the tax expenditure use is evaluated through the aspects of the existence of reasonable objectives which is demonstrated by means of SMART criteria, and the effectiveness disclosed by regressive analysis. Third, the impact upon the collection and use control is assessed on the basis of the quality content analysis with a view to identifying whether the relevant legal acts provide for mechanisms of for estimation of revenue loss and control over the use of tax expenditure, and whether such mechanisms function in practice.

By applying the proposed model to the tax incentives referred to in Article 21 of the LITI of the RL the study concluded that the ITI incentives for life insurance premiums, fees for studies or vocational training, or pension contributions to pension accumulation funds in general produce negative effect upon public finance. The use of the model not only allows to arrive to the conclusion, but also shows the areas to be improved with respect to each incentive.

The ITI incentive for life insurance contributions lead to significant budget revenue loss which has been lately increasing; despite a strong correlation between the loss in the budget revenue and the level of poverty, and important conclusion is that in the context of the incentive the objective of its application was not clearly defined, and it remains unclear what and to what extent it is sought to be achieved. As no mechanism for collection of revenue foregone or monitoring of the use of tax expenditure, the functioning of the incentive is not controlled in any way.

The ITI incentive for the fees for studies does not have any significant fiscal impact upon the budget, the study showed a link and dependence between the number of specialists trained by universities and the revenue loss due to the application of the incentive. However, the objective pursued by introducing the incentive in the tax structure is overly excessive, its relevance for the society is questionable (which is also demonstrated by a relatively low take-up level); furthermore, the transparency of the tax structure is compromised because of the absence of a procedure for monitoring the revenue lost because of the incentive and its effectiveness.

The loss of the State budget because of the incentive for contributions to pension funds are insignificant, and the high take-up level provides an evidence that the incentive is highly relevant. The relation between the budget loss because of the ITI incentives for pension contributions and the relative number of persons saving in pension funds is an evidence of the theoretical suitability of the incentive as a means to promote saving in private funds. To achieve a positive impact upon public finance the tax structure must provide for a definition of the incentive's objective and design a mechanism for control of lost income and tax expenditure.

Having regard to the results of evaluation of the impact of the incentives upon public finance, the authors of the present paper suggest that the ITI incentives for life insurance premiums, fees for studies and/or vocational training, and contributions to pension funds be reviewed, while particularly highlighting on the expediency of such incentives, also providing for a mechanism for collecting revenues and monitoring of the use of tax expenditures; such mechanism must ensure a possibility of a periodic assessment an review of the efficiency and necessity of such incentives. 


\section{References}

Afonso, A., Ebert, W., Schuknecht, L., Thöne, M. 2005. Quality Of Public Finances And Growth. Working Paper Series. Frankfurt: European Central Bank. Available: https://core.ac.uk/download/pdf/6956323.pdf

Barrios, S., Schaechter, A. 2009. Gauging by numbers: A first attempt to measure the quality of public finances in the EU. Economic Papers 382. https://doi.org/10.2765/39172

Barrios, S., Fatica, S., Martinez-Lopez, D., Mourre, G. 2018. The Fiscal Effects of Work-related Tax Expenditures in Europe. Public Finance Review 46 (5): 792-822. Available: https://journals.sagepub.com/toc/pfrb/46/5

Brown, C. 2004. Tax Expenditures in Australia. In the Tax Expenditures - Shedding Light on Government Spending through the Tax System: Lessons from Developed and Transition Economies, ed. World Bank: 45-61.

Carasso, A., Steuerle, C.E. 2003. Tax Expenditures: Revenue Loss Versus Outlay Equivalents. Available: http://www.urban.org/sites/ default/files/alfresco/publication-pdfs/1000568-Tax-Expenditures-Revenue-Loss-Versus-Outlay-Equivalents.PDF

Collins, L., Walsh, M. 2011. Tax Expenditures: Revenue And Information Forgone - The Experience Of Ireland. Tep Working Paper No. 1211. Available: https://www.tcd.ie/Economics/TEP/2011/TEP1211.pdf

Committee of Budget and Finance of the Seimas of the Republic of Lithuania. 2016. Pagrindinio komiteto išvada dèl Gyventojų pajamu mokesčio įstatymo Nr. IX-1007 17 ir 21 straipsnių pakeitimo ịstatymo projekto [Principal Committe Conclusion on the Draw Law amending Articles 17 and 21 of the Law on Income Tax of Individuals of the Republic of Lithuania, No. IX-1007]. Available: https://eseimas.lrs.lt/portal/legalAct/lt/TAK/f84df1e0c39511e682539852a4b72dd4?jfwid=89x1tjog0

Committee on Budget and Finance of the Seimas of the Republic of Lithuania. 2002. Pagrindinio komiteto išvados projektas dèl Lietuvos Respublikos gyventojų pajamų mokesčio įstatymo projekto Nr. IXP-1574 [Principal Committe Draft Conclusion on the Draft Law on Income Tax of Individuals of the Republic of Lithuania No. IXP-1574]. Available: https://e-seimas.lrs.lt/portal/legalact/lt/tak/ tais. 168107 ? jfwid $=89 \times 1$ tjcj4

Commonwealth of Australia House of Representatives Standing Committee on Tax and Revenue. 2015. The Tax Expenditures Statement. Canberra: The Parliament of the Commonwealth of Australia. Available: https://www.treasury.gov.au/ /media/Treasury/ Publications\%20and\%20Media/Publications/2016/Tax\%20Expenditures\%20Statement\%202015/Downloads/PDF/2015 TES.ashx

Commonwealth of Australia. 2017. Tax Expenditures Statement. Available: https://static.treasury.gov.au/uploads/sites/1/2017/06/TaxExpenditure-Statement-2016.pdf

Dalton, H. 1986. Principles of Public Finance. London: Routledge.

Davidson, S. 2012. Mining taxes and subsidies: official evidence. Available: http://www.minerals.org.au/file_upload/files/publications/ mca_backgrounder_FINAL.pdf

Dean, S.A. 2012. The Tax Expenditure Budget Is a Zombie Accountant. University of California, Davis Law Review 46: $267-312$. Available: http://lawreview.law.ucdavis.edu/issues/46/1/Articles/46-1_Dean.pdf

Department of Finance, Canada. 2017. Report on Federal Tax Expenditures - Concepts, Estimates and Evaluations 2017. Available: : https://www.fin.gc.ca/taxexp-depfisc/2017/taxexp17-eng.asp

Department of Finance, Ireland. 2014. Report On Tax Expenditures: Incorporating Department of Finance Guidelines for Tax Expenditure Evaluation. Available: http://www.budget.gov.ie/Budgets/2015/Documents/Tax_Expenditures_Oct14.pdf

Department of Finance, Ireland. 2016. Report on Tax Expenditures. Available: http://www.budget.gov.ie/Budgets/2017/Documents/ Tax_Expenditures_Report\%202016_final.pdf

Doran, G. T. 1981. There's a S.M.A.R.T. way to write management's goals and objectives. Management Review 70(11): 35-36. Available: http://community.mis.temple.edu/mis0855002fall2015/files/2015/10/S.A.R.T-Way-Management-Review.pdf

Gertler, P. J., Martinez, S., Premand, P., Rawlings, L. B., Vermeersch, Ch.M. J. 2016. Impact Evaluation in Practice. Washington, DC: The World Bank. https://doi.org/10.1596/978-0-8213-8541-8

Hashimzade, N., Heady, C., Myles, G., Oats, L., Scharf, K., Youse, H. 2014. The Definition, Measurement, and Evaluation of Tax Expenditures and Tax Reliefs. TARC National Audit Office Technical paper. Available: https://www.nao.org.uk/wp-content/ uploads/2014/03/TARC-Tax-Expenditures-and-tax-reliefs-technical-paper.pdf

Jacobsen, R., Gebauer, A., Mellbye, K., Pukander, F., Kari, S., Olsen, S., Lindvall, L. 2010. Tax Expenditures in the Nordic Countries. 
Available: http://www.skdk/media/110391/tax_expenditures_in_the_nordic_countries.pdf

Katina, J.; Sansyzbayeva, G. N.; Guliyeva, A.; Rzayeva, U. 2018. Threats to the country's sustainable economic development: a case study, Journal of Security and Sustainability Issues 8(1): 113-122. https://doi.org/10.9770/jssi.2018.8.1(10)

Law on Income Tax of Individuals of the Republic of Lithuania. TAR, 2015-12-21, Nr. 20135. Available: https://www.e-tar.lt/portal/lt/ legalAct/598b01e0a7f011e5be7fbe3f919a1ebe

Luzgina, A. 2017. Problems of corruption and tax evasion in construction sector in Belarus, Entrepreneurship and Sustainability Issues 5(2): 263-282. http://doi.org/10.9770/jesi.2017.5.2(8)

Meidūnas, V., Puzinauskas, P. 2003. Finansai [Finance.] Vilnius: Teisinès informacijos centras, 123.

Ministry of Finance of the Republic of Lithuania. 2002. Aiškinamasis raštas dèl Lietuvos Respublikos gyventojų pajamų mokesčio istatymo projekto [The explanatory note on project of the Law on Income Tax of Individuals of the Republic of Lithuania]. Available: https://eseimas.lrs.lt/portal/legalAct/lt/TAK/TAIS165488?jfwid=89x1tjcj4

Ministry of Finance of the Republic of Lithuania. 2008. Gyventojų pajamų mokesčio ịstatymo 2, 3, 5, 6, 7, 8, 9, 10, 12, 131, 16, 17, 18, $19,20,21,22,23,27,29,30$ straipsnių pakeitimo ir papildymo ir İstatymo papildymo 18(1) straipsniu ịstatymo projekto aiškinamasis raštas [The explanatory note on the Law amending Articles 2, 3, 5, 6, 7, 8, 9, 10, 12, 131, 16, 17, 18, 19, 20, 21, 22, 23, 27, 29, 30 and supplementing Article 18(1) of the Law on Income Tax of Individuals of the Republic of Lithuania]. Available: https://e-seimas.lrs.lt/ portal/legalAct/lt/TAK/TAIS.333070?jfwid=89x1tjo7u

Öberg, S. 2010. Offentliga finanser och penningpolitik. Anförande [Public Finance anf Monetary Policy. Speech]. Stockholm: Sveriges Riksbank. Available: http://www.riksbank.se/Upload/Dokument_riksbank/Kat_publicerat/Ta1/2010/100426.pdf

OECD. 2006. Outline of Principles of Impact Evaluation. Available: http://www.oecd.org/dac/evaluation/dcdndep/37671602.pdf

OECD. 2010a. Tax Expenditures in OECD Countries. Paris: OECD Publishing. https://doi.org/10.1787/9789264076907-en

OECD. 2010b. OECD Tax Policy Studies Choosing a Broad Base - Low Rate Approach to Taxation. https://doi.org/10.1787/9789264091320-en

Osipov, G.V., Glotov, V.I., Karepova, S.G. 2018. Population in the shadow market: petty corruption and unpaid taxes, Entrepreneurship and Sustainability Issues 6(2): 692-710. http://doi.org/10.9770/jesi.2018.6.2(16)

Pitter, A. 2013. A Report on the Massachusetts Film Industry Tax Incentives. Available: http://www.mass.gov/dor/docs/dor/news/ reportcalendaryear2011.pdf

Polackova Brixi, H., Valenduc, C. A., Swift, Z.L. 2004. Tax expenditures - shedding light on government spending through the tax system: Lessons from developed and transition economies. Washington: World Bank. Available: https://openknowledge.worldbank.org/ handle/10986/15067

Rabin, J. 1992. Handbook of Public Budgeting. New York: Marcel Dekker, 623.

Rashkin, D. 2007. Practical Guide to Research and Development Tax Incentives: Federal, State, and Foreign. Chicago: CCD, 450.

Redonda, A. 2016. Tax Expenditures and Sustainability. An Overview. CEP Discussion Note 2016/3. Available: https://www.cepweb. org/wp-content/uploads/CEP-DN-Tax-Expenditures-and-Sustainability.-An-Overview.pdf

Redonda, A., Diaz de Sarralde, S., Hallerberg, M., Johnson, L., Melamud, A., Rozemberg, R., Schwab, J., Haldenwang, Ch. (2018). Tax expenditure and the treatment of tax incentives for investment. Discussion Papers, 2018-57, Kiel Institute for the World Economy. Available: http://www.economics-ejournal.org/economics/discussionpapers/2018-57

Roin, J. 2003. Truth in Government: Beyond the Tax Expenditure Budget. Hastings Law Journal. Available: https://ssrn.com/ abstract $=350981$

Shanks-Booth, D., Mettler, S. (2019). The Paradox of the Earned Income Tax Credit: Appreciating Benefits but not Their Source. Policy Studies Journal Special Issue Paper. https://doi.org/10.1111/psj.12305

Stern, E., Stame, N., Mayne, J., Forss, K., Davies, R., Befani, B. 2012. Broadening the range of designs and methods for impact evaluations. Report of a study commissioned by the Department for International Development. Available: https://www.gov.uk/ government/uploads/system/uploads/attachment_data/file/67427/design-method-impact eval.pdf

Sveriges Regeringen.2016. Regeringens skrivelse2015/16:98:Redovisningavskatteutgifter 2016 [GovernentCommunication2015/16:98: Recognitiong of Tax Charges 2016]. Available: http://www.regeringen.se/496f5e/contentassets/a03cbccab52a400ea408c518a9c05f73/ 
redovisning-av skatteut gifter-2016-skr.-20151698

Tarasova, V.I., Mezdrykov, Y. V., Efimova, S.B., Fedotova, E.S., Dudenkov, D. A., Skachkova, R.V. 2018. Methodological provision for the assessment of audit risk during the audit of tax reporting, Enterpreneurship and Sustainability Issues 6(1): 371-397. http://doi. org/10.9770/jesi.2018.6.1(23)

Thöne, M. 2012. 18 Billion at One Blow - Evaluating Germany’s Twenty Biggest Tax Expenditures. Proceedings. Annual Conference on Taxation and Minutes of the Annual Meeting of the National Tax Association. 104: 41-51. Available: http://www.jstor.org/stable/ prancotamamnta.104.41

Tipps, D. C., Webb, L. 1980. State and Local Tax Revolt: New Directions for the '80s. Washington, D.C.: Conference on Alternative State \& Local Policies.

Tvaronavičienè, M. 2018. Toward efficient policy making: forecasts of vulnerability to external global threats, Journal of Security and Sustainability Issues 7(3): 591-600. https://doi.org/10.9770/jssi.2018.7.3(18)

Tyson, A. 2014. Reforming Tax Expenditures in Italy: What, Why, and How? IMF Working Papers. Available: https://www.imf.org/ external/pubs/ft/wp/2014/wp1407.pdf

U.S. Department of The Treasury. 2017. Tax Expenditures. Available: https://www.treasury.gov/resource-center/tax-policy/Documents/ Tax-Expenditures-FY2018.pdf

Vandina, O.; Mkrtychan, Z.; Denisov, I.; Vechkinzova, Y. 2018. The tax mechanism of managing the process of formation of information economy in modern Russia, Entrepreneurship and Sustainability Issues 6(2): 830-839. https://doi.org/10.9770/jesi.2018.6.2(24)

\section{Biographical notes:}

Dr. oec. Greta KELIUOTYTĖ-STANIULĖNIENĖ - Assistant Professor at Faculty of Economics and Business Administration, Vilnius University, Lithuania. Research interest covers: Financial markets, Financial institutions, Financial stability, Public finance, Taxation.

Asta MIRONENKO - Master of Econimics (Finance), Faculty of Economics and Business Administration, Vilnius University, Lithuania. 